\title{
THE PRESIDENT'S REPORT
}

A year ago the Regina Natural History Society decided to help publish the BLUE JAY. The Provincial Museum of Natural History in Regina had been paying the printing costs but others in Regina had taken no responsibility for the editorial work. We felt that the Museum should be relieved of the costs which it had been contributing to our society. We all agreed that an editor has a great amount of work to do in assembling material and that he must receive remuneration.

The Yorkton Natural History Society gave us every encouragement and allowed us to elect provisional officers of the Saskatchewan Natural History Society. All those subscribing to the BLUE JAY would be members of this society. The fee was raised to one dollar per year since the majority of those answering the questionnaire were in favor of this increase. Nr. I. T. Carmichael agreed to be our editor.

We had our first annual meeting in october. This year the meeting had to spend much of its time adopting a constitution. A copy of our constitution is printed elsewhere in the BLUE JAY. It is drawn up in accord with our experiences of this year. No doubt changes in it will be necessary as the society changes and develops but these changes can be incorporated an an annual meeting after notice has been given in the BLUE JAY.

Enthusiastic members came to the annual meeting from Swift Current, Burnham, Moose Jaw, Naicam, Indian Head and Grenfell. Bob McKenzie gave an interesting address on the early history of Saskatchewan with particular $r e f e r e n c e$ to the wild life ninety years ago in comparison with that of today. Doug Gilroy showed some excellent kodachrome natural history pictures taken on his farm near the Qu'Appelle Valley... Ducks Unlimited favored us with that beautiful colorcd movie Prairie Wings.

The report of the secretary-treasurer revealed 270 paid-up members in our society. Each issue of the BLUE JAY costs nearly. \$100.00. There was no talk of raising the membership dues to make our books balance. It was agreed that every effort should be made to increase our membership list. The responsibility for this work should rest mainly on the directors who are widely separated throughout the province. The idea of patrons (see constitution) was endorsed so that money could be accepted from the members and acknowledged in the BLUE JAY:

There was no time during the meeting to discuss the editorial policy of the BLUE JAY. Our editor has agreed to receive all membership dues. This. is extra work for him but you can help by writing items of interest when you send in your dollar. The executive will share with the editor the heavy load of mimeographing and getting the BLUE JAY into the mail. The editor in his report spoke of possible improvements in the BLUE JAY. Perhaps we can have lots of pictures in one of our 1950 issues. This, of course, would cost more so let's get the memberships in and try to increase our bank balance.

The officers of the provisional society who were elected in January were re-elected at our annual meeting. It was stressed that they should serve at least a full year. Because of certain changes brought in by the constitution additions were necessary and these appear on the front page. Your president and other re-elected officers wish to express their appreciation for the conflience shown in them by thos particlpating in the election, including those who 
wote in preceding the meeting. Please remember, for future years, you do not have to be present at the annual meeting to make a nomination or to register a vote.

We have successfully met the dead lines in publishing the four 1949 issues of the BLUE JAY. Thanks to the aid given this year by the Museum we have met our costs without dipping too deeply into 1950 membership monies. our confidenoe in the success of our society is growing. We will do better in 1950.

This is your society and it must depend on you if it is to live up to its aims and its plans for the future. Help us to keep expenses to a minimum. Send in your membership dues before special reminders have to be sent to you. Let's all get out and find new members and send in more stories. Let's make the BLUE JAY more successful in 1950 than it has been in 1949.

- G. F. Iedingham

\section{PATRONS FOR 1950}

We acknowledge with thanis the donations received, up to the time of going to press, of those desircus of being listed as Patrons of the Saskatchewan Natural History Society for 1950.

\begin{tabular}{lr} 
Miss Pauline Summers, Yorkton, & $\$ 15.00$ \\
C. C. Shaw, Yorkton & 6.00 \\
Fred Langstaff, Yorkton & 5.00 \\
Stuart Houston, Winnipeg & 5.00 \\
L. T. Carmichael, Regina & 5.00 \\
Id Brooman, Prince Albert & 5.00 \\
Regina Natural History Society & 50.00 \\
Yorkton Natural History Society & 20.00 \\
\multicolumn{1}{c}{ YoRKTON ACTIVITY } &
\end{tabular}

our thanks is extended in particular, at this time, to our Vice President, Cliff Shaw, of Yorkton, through whose untiring efforts, sixtyfive new members have recently subscribed to the BLUE JAY for the coming year. of this number thirty-one subscriptions were solicited from teachers attending institute meetings in Yorkton, during the week-end of october 28.

A subscriber from Yorkton, who desires to remain anonymous, has paid for nine 1950 subscriptions of the BLUE JAY. Three are to go to the Nature Clubs of each of the three public schools of Yorkton; Simpson, Burke and Victoria. 